\title{
THE TREATMENT OF FLEXION CONTRACTURES OF THE KNEE IN POLIOMYELITIS
}

\author{
Alan N. Conner, Glasgow, Scotland
}

In some parts of the world poliomyelitis is still endemic and there are thousands of young people with joint contractures (Fig. 1). These most commonly occur at the knee, and the aim of treatment must be a straight knee with a useful range of painless flexion so that a hinged caliper can be worn. This paper reports experience in correcting flexion contractures of the knee following poliomyelitis and advises a regime which improves the results.

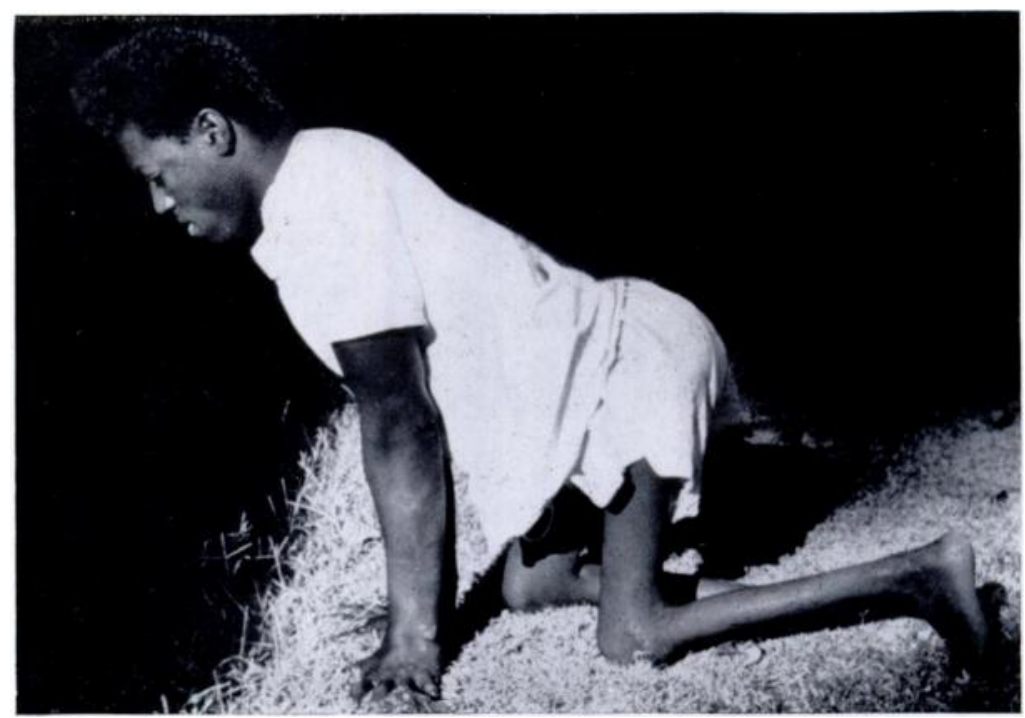

FiG. 1

Case 1-Severe flexion contractures of both knees.

Since the turn of the century hamstring tenotomy followed by manipulation has been the accepted treatment of flexion contractures of the knee (Bradford and Lovett 1900). In 1926 Yount demonstrated the importance of the tensor fasciae latae muscle as a deforming force and advised its division. Wilson (1929) recommended posterior capsulotomy as a preliminary to manipulation. These methods produced a straight knee but in severe deformities they often led to posterior subluxation of the tibia on the femur, so that the joint was stiff and painful. To prevent this complication hinged splints (Cravener 1930), hinged plasters (Hart 1934) and balanced traction (Haas 1938) have all been advised.

A recent year spent at the only orthopaedic unit in the Republic of Kenya enabled an assessment of the results of these methods to be made and the causes of subluxation analysed.

\section{CLINICAL OBSERVATIONS}

Nineteen patients in whom flexion deformities of the knee had been corrected by division of the hamstring tendons and ilio-tibial band followed by serial manipulations were reviewed. In ten patients the deformity was bilateral, so that twenty-nine knees were studied. In all, the 
TABLE I

Detalls of Nine Knees in the Congruous Group

\begin{tabular}{|c|c|c|c|c|c|c|c|}
\hline $\begin{array}{c}\text { Case } \\
\text { number }\end{array}$ & Sex & $\begin{array}{c}\text { Age } \\
\text { (years) }\end{array}$ & Side & $\begin{array}{c}\text { Deformity } \\
\text { (degrees) }\end{array}$ & Treatment & Pain & $\begin{array}{l}\text { Result } \\
\begin{array}{c}\text { Passive range } \\
\text { of flexion } \\
\text { (degrees) }\end{array}\end{array}$ \\
\hline 4 & Male & 8 & Left & 40 & Serial manipulation and plasters & No & 90 \\
\hline 5 & Male & 6 & Right & 30 & Serial wedged plasters & No & 90 \\
\hline 7 & Female & 16 & Right & 30 & Serial manipulation and plasters & No & Over 90 \\
\hline 10 & Male & 12 & $\begin{array}{l}\text { Right } \\
\text { Left }\end{array}$ & $\begin{array}{l}90 \\
90\end{array}$ & $\begin{array}{l}\text { Serial wedged plasters } \\
\text { Serial wedged plasters }\end{array}$ & $\begin{array}{l}\text { No } \\
\text { No }\end{array}$ & $\begin{array}{l}\text { Over } 90 \\
\text { Over } 90\end{array}$ \\
\hline 14 & Female & 7 & $\begin{array}{l}\text { Right } \\
\text { Left }\end{array}$ & $\begin{array}{l}35 \\
35\end{array}$ & $\begin{array}{l}\text { Serial wedged plasters } \\
\text { Serial wedged plasters }\end{array}$ & $\begin{array}{l}\text { No } \\
\text { No }\end{array}$ & $\begin{array}{l}\text { Over } 90 \\
\text { Over } 90\end{array}$ \\
\hline 17 & Male & 7 & Left & 30 & Serial manipulation and plasters & No & Over 90 \\
\hline 19 & Male & 18 & Right & 30 & Serial manipulation and plasters & No & 90 \\
\hline
\end{tabular}

TABLE II

Detalls of Thirteen Knees in the Subluxated Group

\begin{tabular}{|c|c|c|c|c|c|c|c|}
\hline $\begin{array}{c}\text { Case } \\
\text { number }\end{array}$ & Sex & $\begin{array}{c}\text { Age } \\
\text { (years) }\end{array}$ & Side & $\begin{array}{l}\text { Deformity } \\
\text { (degrees) }\end{array}$ & Treatment & Pain & $\begin{array}{l}\text { Result } \\
\text { Passive range } \\
\text { of flexion } \\
\text { (degrees) }\end{array}$ \\
\hline \multirow{2}{*}{2} & \multirow{2}{*}{ Male } & \multirow{2}{*}{14} & & 80 & \multirow{2}{*}{$\begin{array}{c}\text { Tenotomy, serial manipulation } \\
\text { and plasters } \\
\text { Tenotomy, serial manipulation } \\
\text { and plasters }\end{array}$} & No & 30 \\
\hline & & & Left & 80 & & Yes & 30 \\
\hline \multirow{2}{*}{3} & \multirow{2}{*}{ Male } & \multirow{2}{*}{7} & Right & 90 & \multirow{2}{*}{$\begin{array}{c}\text { Tenotomy, serial manipulation } \\
\text { and plasters } \\
\text { Tenotomy, serial manipulation } \\
\text { and plasters }\end{array}$} & Yes & 40 \\
\hline & & & Left & 90 & & No & 60 \\
\hline 5 & Male & 6 & Left & 45 & Tenotomy, serial wedged plasters & No & 30 \\
\hline 9 & Female & 10 & Right & 45 & Serial manipulation and plasters & Yes & 45 \\
\hline 11 & Female & 14 & Left & 90 & Tenotomy, serial wedged plasters & Yes & 20 \\
\hline 13 & Male & 15 & $\begin{array}{l}\text { Right } \\
\text { Left }\end{array}$ & $\begin{array}{l}90 \\
90\end{array}$ & $\begin{array}{l}\text { Tenotomy, serial wedged plasters } \\
\text { Tenotomy, serial wedged plasters }\end{array}$ & $\begin{array}{l}\text { Yes } \\
\text { No }\end{array}$ & $\begin{array}{l}30 \\
60\end{array}$ \\
\hline 15 & Male & 7 & $\begin{array}{l}\text { Right } \\
\text { Left }\end{array}$ & $\begin{array}{l}90 \\
90\end{array}$ & $\begin{array}{l}\text { Tenotomy, serial wedged plasters } \\
\text { Tenotomy, serial wedged plasters }\end{array}$ & $\begin{array}{l}\text { Yes } \\
\text { Yes }\end{array}$ & $\begin{array}{l}45 \\
30\end{array}$ \\
\hline 16 & Female & 7 & Right & 90 & $\begin{array}{c}\text { Tenotomy, serial manipulation } \\
\text { and plasters }\end{array}$ & Yes & 30 \\
\hline 18 & Male & 17 & Left & 45 & Tenotomy, serial wedged plasters & Yes & 20 \\
\hline
\end{tabular}


TABLE III

Dhtalls of Seven Knefs in thi: Dislocatid Group

\begin{tabular}{|c|c|c|c|c|c|c|c|}
\hline $\begin{array}{c}\text { Case } \\
\text { number }\end{array}$ & Sex & $\underset{(\text { years })}{\text { Age }}$ & Side & $\begin{array}{l}\text { Deformity } \\
\text { (degrees) }\end{array}$ & Treatment & Pain & $\begin{array}{l}\text { Result } \\
\text { Passive range } \\
\text { of flexion } \\
\text { (degrees) }\end{array}$ \\
\hline 1 & Male & 16 & Right & 90 & $\begin{array}{l}\text { Tenotomy and posterior } \\
\text { capsulotomy with cruciate } \\
\text { division. } \\
\text { Serial manipulation and plasters } \\
\text { Tenotomy and posterior } \\
\text { capsulotomy with cruciate } \\
\text { division. } \\
\text { Serial manipulation and plasters }\end{array}$ & Yes & 35 \\
\hline 6 & Male & 8 & Left & 90 & Tenotomy, serial wedged plasters & Yes & 45 \\
\hline 8 & Male & 14 & $\begin{array}{c}\text { Right } \\
\text { Left }\end{array}$ & $\begin{array}{r}100 \\
80\end{array}$ & $\begin{array}{l}\text { Tenotomy, serial wedged plasters } \\
\text { Tenotomy, serial wedged plasters }\end{array}$ & $\begin{array}{l}\text { Yes } \\
\text { Yes }\end{array}$ & $\begin{array}{l}20 \\
30\end{array}$ \\
\hline 11 & Female & 14 & Right & 90 & Serial wedged plasters & Yes & 30 \\
\hline 12 & Female & 10 & Right & 90 & Serial wedged plasters & Yes & 45 \\
\hline
\end{tabular}

leg was straight and it was possible to fit a caliper; but lateral radiographs showed that after correction only two of nineteen knees in which there had been an initial deformity of 70 degrees or more were congruous. It was a striking finding that all the knees which had a useful range of painless movement fell in the group of congruous joints. Tables I, II and III show how the result is directly related to the degree of posterior displacement of the tibia. Figure 2 shows the radiograph of a patient in the group without congruity. Although such knees were straight they were so painful that even walking with crutches was difficult.

The second important finding was that the

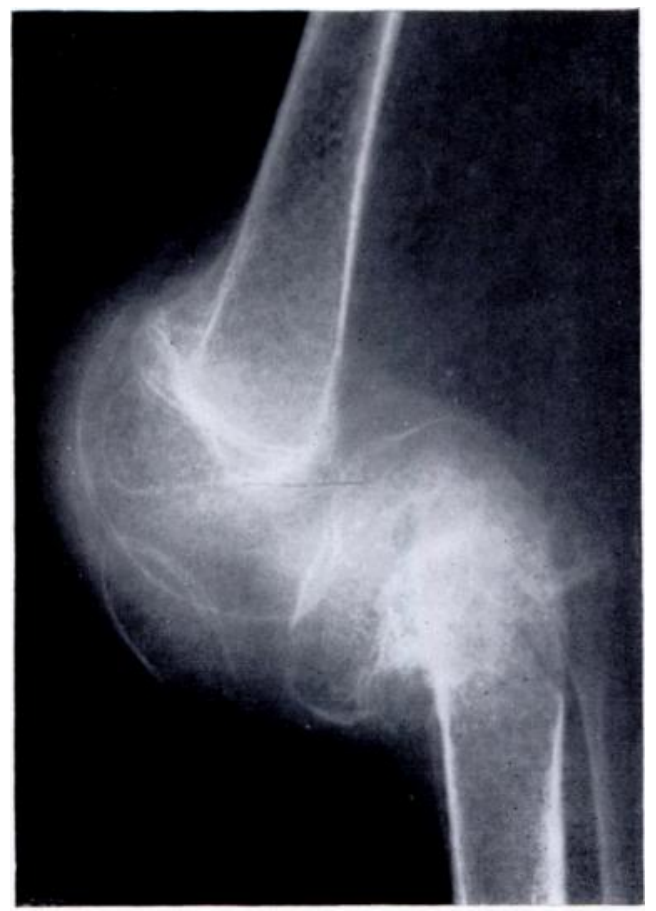

FIG. 2 tight posterior capsule could usually be stretched quite adequately by manipulation and serial plasters. In severe deformities in which posterior subluxation had occurred because of attempted correction, the posterior capsule had been stretched more than would have been required if the joint had remained congruous. The recurrent difficulty was to bring the tibial plateau forward on the femoral condyles.

\section{ANATOMY}

The knee is a pure hinge joint although the last five degrees of extension are accompanied by medial rotation of the femur on the tibia. This tightens the collateral ligaments and oblique posterior ligament and locks the extended knee (Last 1959). The axis of movement, however,

\section{Fig. 2}

Case 8-Radiograph showing false correction after treatment of an 80 degrees flexion contracture of the knee by tenotomy and serial wedged plasters. 


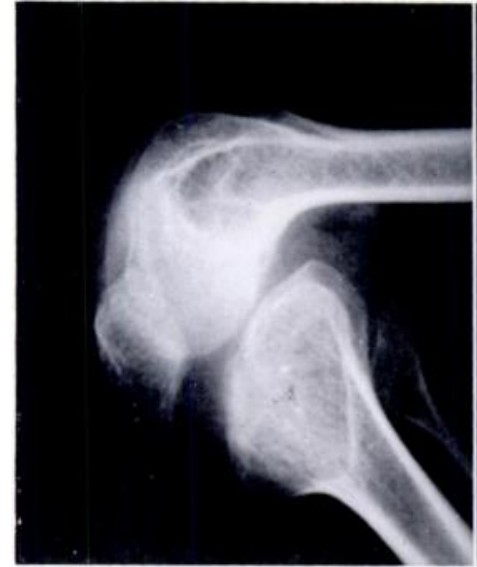

FiG. 3

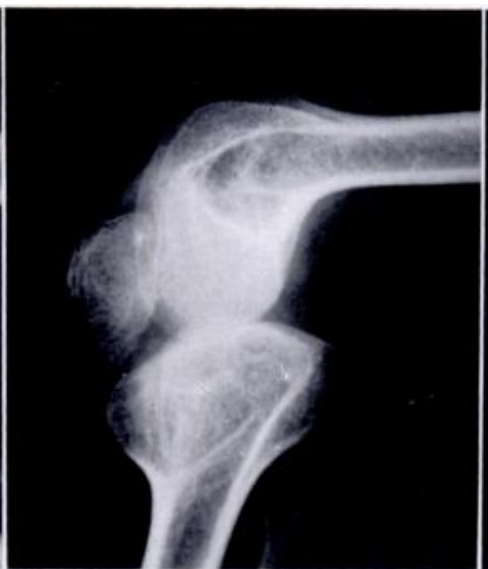

FIG. 4

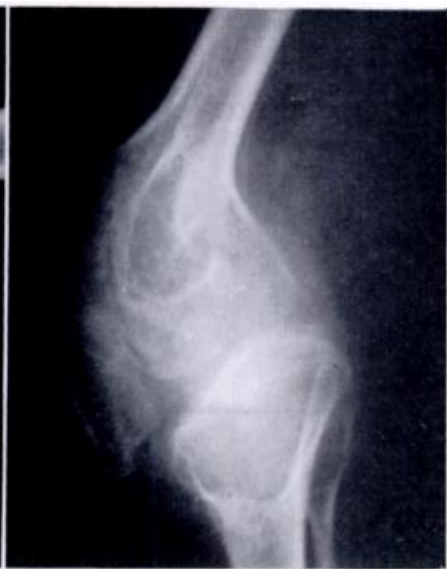

FIG. 5

Case 1. Figure 3-Radiograph of a knee taken in full flexion. Figure 4-The same knee in the position of contracture. Figure 5-After correction to demonstrate the abnormal rocking motion which takes place. The low position of the patella is also seen.

does not pass through the joint line but through the upper attachments of the collateral ligaments, so that the tibial plateau glides forward on the femoral condyles.

The deformity is caused in the first instance by the unopposed action of the hamstrings, and in early cases the resultant contracture can be easily overcome by stretching or tenotomy. If treatment is delayed secondary changes take place in the joint capsule and correction becomes more difficult, so that the immediate improvement after division of the hamstrings and ilio-tibial band may be no more than twenty degrees.

When radiographs of the knees in this series were studied it was apparent that the normal gliding movement did not take place when severe flexion deformities were corrected. Instead, the axis of movement approached the joint line and a simple rocking motion occurred (Figs. 3 to 5). It was possible to study the intra-articular anatomy of the deformity in six knees, two of which were treated by posterior capsulotomy and division of the cruciates, two by supracondylar osteotomy of the femur and two by arthrodesis.

A low position of the patella in the intercondylar notch of the femur was a common finding in severe deformity (Figs. 3 to 5 ) and it was thought that the patella might act as a block to correction by preventing the tibia from coming forward. This was not confirmed at operation. Furthermore the evidence that the anterior cruciate ligament was important in preventing correction was unconvincing. Division of the cruciates made no immediate difference to the degree of deformity. Neither did posterior capsulotomy in the two cases in which it was done. The significant operative finding was that the quadriceps expansion, blending with the joint capsule and collateral ligaments, appeared to form an adherent hood over the femoral condyles so that there were no lateral joint recesses. It was therefore impossible for the collateral ligaments to glide over the underlying bone. This had the effect of bringing the axis of joint movement towards the joint line.

\section{TREATMENT}

Because shortening of the collateral structures appeared to be the cause of false correction a technique of manipulation to overcome this was used. The condylar region of the tibia was carefully pulled forward on the femur (Figs. 6 and 7) so that the flexion deformity was corrected by the normal gliding movement of the knee joint. In this way all the tight soft tissues were stretched. 
Eleven severely flexed knees in children up to the age of fifteen were treated by this method. In six knees the hamstring tendons and ilio-tibial band were divided first.

Serial manipulations were done on five joints at two-weekly intervals under general anaesthesia, the new position being held by a plaster cylinder. Four to six manipulations were

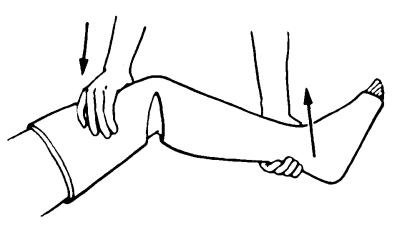

FIG. 6

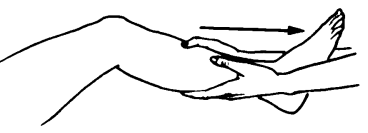

Diagrams to show the methods of manipulation which lead to subluxation (Fig. 6) and the recommended

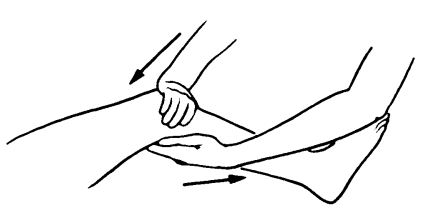

FIG. 7 method (Fig. 7).

needed to straighten the knees fully. In the other six joints continuous skin traction was used to support the joint, and the manipulations were performed daily without anaesthesia until the deformity was 40 degrees. After the knee had been rested in plaster for four weeks one manipulation under anaesthesia corrected the remaining deformity.

\section{RESULTS}

Ten out of eleven knees were fully corrected and congruous (Table IV) with a painless range of movement of more than 0 to 90 degrees.

TABLE IV

Detalls of Eleven Severe Flexion Contractures Treated by the Recommended Method

\begin{tabular}{|c|c|c|c|c|c|c|c|}
\hline \multirow[b]{2}{*}{$\begin{array}{c}\text { Case } \\
\text { number }\end{array}$} & \multirow[b]{2}{*}{ Sex } & \multirow[b]{2}{*}{$\underset{\text { (years) }}{\text { Age }}$} & \multirow[b]{2}{*}{ Side } & \multirow[b]{2}{*}{$\begin{array}{l}\text { Deformity } \\
\text { (degrees) }\end{array}$} & \multirow[b]{2}{*}{$\begin{array}{c}\text { Initial } \\
\text { hamstring } \\
\text { tenotomy }\end{array}$} & \multicolumn{2}{|r|}{ Result } \\
\hline & & & & & & Pain & $\begin{array}{l}\text { Passive range } \\
\text { of flexion } \\
\text { (degrees) }\end{array}$ \\
\hline \multirow{2}{*}{20} & \multirow{2}{*}{ Male } & \multirow{2}{*}{11} & Right & 70 & Yes & No & Over 90 \\
\hline & & & Left & 70 & No & No & Over 90 \\
\hline \multirow{2}{*}{21} & \multirow{2}{*}{ Male } & \multirow{2}{*}{14} & Right & 80 & Yes & No & Over 90 \\
\hline & & & Left & 60 & No & No & Over 90 \\
\hline 22 & Male & 14 & Right & 75 & Yes & No & Over 90 \\
\hline 23 & Male & 13 & Left & 90 & No & Yes & 45 \\
\hline 24 & Male & 14 & Right & 90 & Yes & No & Over 90 \\
\hline 25 & Male & 14 & Left & 80 & Yes & No & Over 90 \\
\hline \multirow{2}{*}{26} & \multirow{2}{*}{ Male } & \multirow{2}{*}{10} & Right & 90 & No & No & Over 90 \\
\hline & & & Left & 90 & No & No & Over 90 \\
\hline 27 & Male & 12 & Right & 80 & Yes & No & Over 90 \\
\hline
\end{tabular}

TREATMENT IN THE OLDER PATIENT

In young adults-or children over the age of fifteen-attempts to gain a straight knee without loss of congruity were disappointing even after extensive soft-tissue operations. In a small series of severe deformities in young adults treatment was by supracondylar osteotomy 


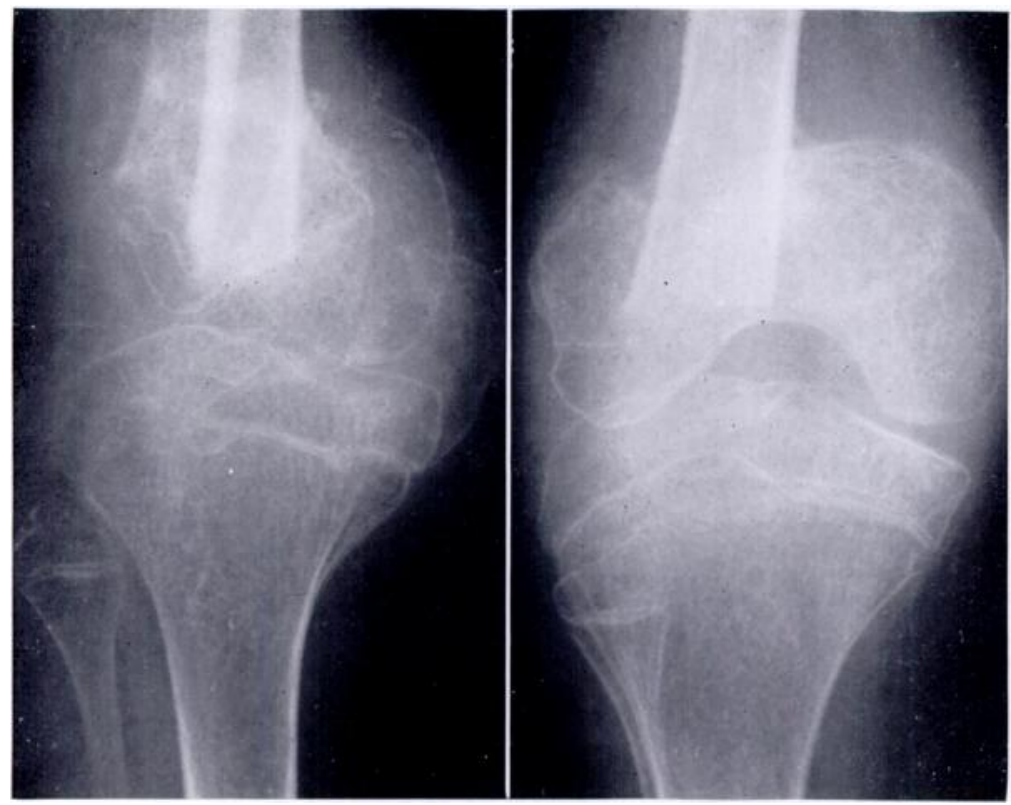

FIG. 8

Radiographs of a knee joint taken eight weeks after supracondylar femoral osteotomy. There is full correction of a 70-degree flexion contracture.

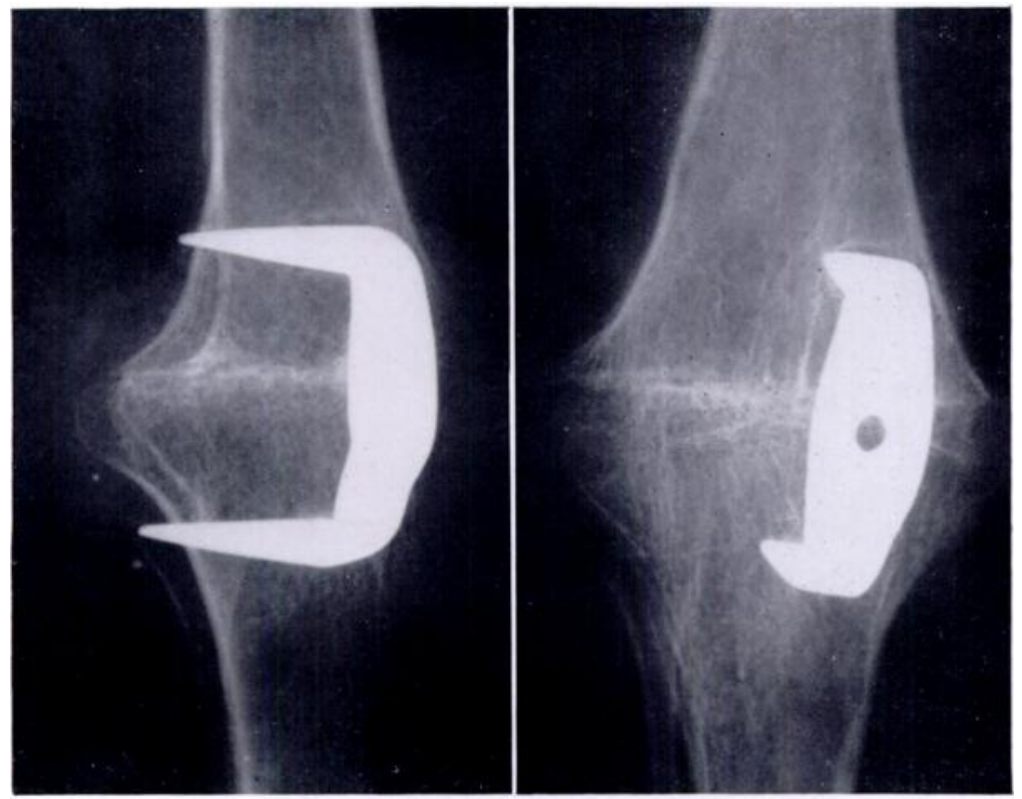

FIG. 9

Radiographs to show union after ten weeks of an arthrodesis of the knee with staple fixation in a man aged 22 who had a 70 -degree flexion contracture. 
of the femur or by arthrodesis of the knee. Osteotomy-in three patients-was most easily done through a lateral approach, with excision of a wedge of bone based anteriorly. Plaster fixation in the corrected position provided good immobilisation until union occurred at eight weeks (Fig. 8). A useful range of painless flexion was preserved in each case.

Arthrodesis was achieved by excising the articular surfaces so that the tight posterior structures acted as a hinge as the joint was straightened. A large staple held the surfaces in close apposition and early weight-bearing in plaster was allowed (Fig. 9). Two patients were treated by this method.

\section{DISCUSSION}

In children under the age of fifteen years a good result can usually be obtained by the treatment described, because careful manipulation and pulling the condylar region of the tibia forward will preserve the joint congruity. Wedged plasters, a common cause of subluxation, are not recommended. Preliminary hamstring tenotomy and division of the ilio-tibial tract are indicated in the more severe cases, but there is no advantage to be gained by posterior capsulotomy: indeed division of the oblique posterior ligament may predispose to posterior subluxation. Preliminary skin traction reduces the number of manipulations needed, an important consideration in areas where general anaesthesia is not widely available.

In long-standing deformities or when manipulation fails (Case 23), supracondylar femoral osteotomy without internal fixation gives good results. Arthrodesis should not be done when there is an associated abduction deformity of the hip, and is of little benefit in the presence of a flail foot because a caliper is still needed. The main indication is in unilateral paralysis with a good hip and a foot in fixed equinus.

\section{SUMMARY}

1. Methods of correcting flexion contractures of the knee following poliomyelitis fail if posterior subluxation of the tibia is allowed to occur.

2. Careful serial manipulations will give straight, congruous joints in younger patients. Posterior capsulotomy does not facilitate correction.

3. Supracondylar femoral osteotomy is indicated in children over fifteen and in adults, although sometimes arthrodesis of the knee is necessary.

I should like to thank Mr N. J. Blockey for his advice and criticism in the preparation of this paper and for the opportunity to study patients under his care. I am also grateful to the Association for the Physically Disabled of Kenya for help in the treatment and follow-up of fifteen of the patients. The illustrations were kindly prepared by the Departments of Medical Illustration of the Royal Hospital for Sick Children, Glasgow, and the Western Infirmary, Glasgow.

\section{REFERENCES}

Bradford, E. H., and LovetT, R. W. (1900): Treatise on Orthopaedic Surgery, p. 486. London: Baillière, Tindall and Cox.

Cravener, E. K. (1930): Device for Overcoming Non-bony Flexion Contractures of the Knee. Journal of Bone and Joint Surgery, 12, 437.

HaAs, S. L. (1938): Correction of Extreme Flexion Contracture of the Knee Joint. Journal of Bone and Joint Surgery, 20, 839.

HarT, V. L. (1934): Corrective Cast for Flexion-contracture Deformity of the Knee. Journal of Bone and Joint Surgery, 16, 970.

LaST, R. J. (1959): Anatomy, Regional and Applied. Second edition, p. 213. London: J. \& A. Churchill Ltd.

WiLson, P. D. (1929): Posterior Capsuloplasty in Certain Flexion Contractures of the Knee. Journal of Bone and Joint Surgery, 11, 40.

Yount, C. C. (1926): The Rôle of the Tensor Fasciae Femoris in Certain Deformities of the Lower Extremities. Journal of Bone and Joint Surgery, 8, 171. 